\title{
Competitiveness in the European Consolidated Banking Sector After the 2008 Financial Crisis
}

\author{
Senanu Kwasi Klutse ${ }^{1}$
}

\begin{abstract}
The constitutional conception of market integration within the European Union entails creating a level playing field for competition in the consolidated banking sector. The financial crisis of 2008 brought with it the need to proceed with care as it rolled back the gains of improving competitive conditions in the financial sector. Even though a lot of studies have investigated competitive conditions prior to the crisis, the same cannot be said of periods after the crisis. Using both structural and non-structural measures of competitive conditions, this study found that the consolidated banking sector in Europe shows signs of a monopolistic competitive market structure based on its revenue and cost measures. As five countries - United Kingdom, France, Germany, Spain, Italy - control about 70 per cent of total assets in the consolidated banking sector. The capital expense to fixed assets and total assets in the Europe area were found to be negatively related to measures of profitability in the sector. They were indicating that the accumulation of assets eats into the incomes of banks in the sub-region, whereas bank exposures may be affecting bank profits.
\end{abstract}

Keywords: Banks, Monopoly, Market Structure

JEL Classification: G21, L12, L11

Received: 15 November 2019/Accepted: 17 August 2020 / Sent for Publication: 7 December 2020

\section{Introduction}

According to Casu and Girardone (2006), the number of banks in the EU decreased by 18 percent between 1997 and 2003. The introduction of the Euro in 1999 and the impact of the financial crisis from 2007 to 2012, with its regulatory reforms, have slowed the evolution of competition in the sub-region. Prior to the financial crisis, arguably, regulatory policies were not strictly enforced or abandoned in favour of pro-competitive policies with the conviction that efficiency and innovation were going to improve. However, the outbreak of the crisis meant more consolidation in countries that have been mostly affected, leading to a restructuring of the banking sectors in these countries.

It is generally expected that increased competition would foster efficiency by providing incentives to managers to cut costs to remain profitable. Recent studies however

\footnotetext{
${ }^{1}$ Institute of Finance and International Economic Relations, University of Szeged, Szeged, Hungary; H-6722 Szeged, Kálvária sgt 1, Hungary; Email: senakluts@live.com; and conditions of the Creative Commons Attribution 3.0 license, Attribution - Non Commercial - No Derivatives.
} 
contradict this view, indicating that the relationship between competition and efficiency is much more complex in the banking sector than in other sectors (Claessens and Laeven, 2004 cited by Casu and Girardone, 2006). Despite this, most theories of competition in the financial sector postulate that competition in the sector leads to the quality of financial services, promotion of innovation, and more importantly, greater access to finance by non-financial sectors and households. On the other hand, financial regulation is seen as anti-competitive as it directly weakens competition through restrictions on bank entries and creates incentives to merge (Leroy and Lucotte, 2017). This feature was more prominent during the 2008 financial crisis and the subsequent implementation of the Basel III agreements the World over.

Generally, the World Economic Forum defines competitiveness as the set of institutions, policies, and factors that determine the level of productivity of a country. The analysis of competitiveness in the consolidated banking sector falls under the eight pillar of the Global Competitiveness Index 2017 - financial market development - which has become an area of focus as a result of the financial crisis in 2008. Due to this, the role of a sound and well-functioning financial sector for economic activities has become very necessary. The average rank ( $8^{\text {th }}$ Pillar) of countries in Europe ${ }^{2}$ in the Global Competitiveness Index from 2007 to 2017 against the GDP per capita average from 2009 to 2017 shows a weak negative relationship between the two (see appendix Figure 1). The focus of the subindicators under the $8^{\text {th }}$ Pillar (financial market development) of the Global Competitiveness Index is premised mostly on technological advancement, which appears to be among the drivers of competition in the financial sector. However, the main drivers of competition in the European Consolidated Banking Sector have often been deregulation, technological changes, market integration - starting with the single market initiative of 1992 and more recently, the global financial crisis of 2008/2009 (Casu and Girardone, 2006).

Most of the studies on competition in the banking or financial sector in the EU have studied competition prior to the financial crisis with little attention to the post-crisis period. Also, as the Global Competitiveness Index seems not to be effective - due in part to the bias of the sub-indicators to technological development - in measuring competitive conditions in the consolidated banking sectors in Europe - this study examines competitive conditions in the consolidated banking sector in Europe after the 2009 financial crisis using both structural (Concentration Ratios) and non-structural (Panzar and Rosse H-statistics) concentration measures.

The results showed that competitive conditions in the consolidated banking sector in Europe exhibits the characteristics of a monopolistic competitive market structure - characteristics of the consolidated banking sector - based on both its revenue and cost measures. The sector was found not to be in equilibrium, violating Panzar and Rosse (1987) assumption of long-run equilibrium and the earning of zero profit for a monopolistic competitive market structure. The study also found that the relative importance of assets, staff

\footnotetext{
${ }^{2}$ Austria, Belgium, Bulgaria, Cyprus, Czech Republic, Denmark, Estonia, Finland, France, Germany, Greece, Hungary, Ireland, Italy, Latvia, Lithuania, Luxembourg, Malta, Netherlands, Poland, Portugal, Romania, Slovak Republic, Slovenia, Spain and United Kingdom.
} 
expenses to the number of employees ratio, and interest expense cannot be overlooked in Europe's consolidated banking sector.

The rest of the paper comprises a brief literature review, a data and methodology section, analysis and discussion of results, and some conclusions.

\section{Literature review}

Studies in bank competition and financial stability have always been a controversial issue among both the academia and policymakers (Leroy and Lucotte, 2017). It is generally expected that increased competition would foster efficiency by providing incentives to managers to cut their costs to remain profitable. Recent studies however, contradict this view indicating that the relationship between competition and efficiency is much more complex in banking than in other industries (Claessens and Laeven, 2004 cited by Casu and Girardone, 2006). For instance, Casu and Girardone (2006) in studying the impact of increased consolidation on competitive conditions of the EU banking market, found that the degree of concentration is not necessarily related to the degree of competition. They found little evidence that more efficient banking systems are also more competitive. Thus, increased competition has forced banks to become more efficient, but increased efficiency did not seem to be fostering a more competitive EU banking system.

Theories of competition in the financial sector also postulate that competition in the sector leads to the quality of financial services, promotion of innovation, and, more importantly, greater access to finance by non-financial sectors and households. This is what Fungáčová, Shamshur, and Weill (2017) referred to as the 'market power hypothesis', which is in line with general economic theory that suggests that greater competition is synonymous with lower prices. Those who oppose this assertion argue that fierce competition may undermine financial stability if banks take excessive risk and invest too little in information collection and establishing a long-term relationship with their customers (Sun, 2011) - a phenomenon also discovered by Leroy and Lucotte (2017). Fungáčová, Shamshur, and Weill (2017) referred to this phenomenon as the 'information hypothesis'.

A lot of studies have investigated competitive conditions in the European financial sector. As early as the 1990s, Molyneux, Lloyd-Williams, and Thornton (1994), studied competitive conditions in major European banking markets between 1986 and 1989. They found that there was a lack of integration in major European banking markets. This was premised on the fact that they found most of the banks in the sector to have earned revenues as if they were under conditions of monopolistic competition and/or conjectural variations short-run oligopoly conditions. Competitive conditions in the Central and Eastern European (CEE) banking sectors have also shown signs of a non-competitive market structure. This was based on a study by Delis (2010), which studied 22 CEE countries for the period 1999 to 2006 (Delis, 2010). Both studies used a non-structured (Panzar and Rosse Hstatistics) measure of competition. Since then, studies have tried to study the impact of a number of variables and events on bank competition in Europe.

Fungáčová, Shamshur, and Weill (2017) studied the impact of bank competition on the cost of credit in a cross-country setting. They were using a panel data set of firms from 20 European countries covering the period 2001-2011. Their study showed that bank competition increases the cost of credit and they found this to be stronger for smaller 
companies. This outcome was found to be influenced by the institutional and economic framework as well as the financial crisis in 2008. Sun (2011) also investigated the degree of bank competition in the Euro area, the US, and the UK, before and after the recent financial crisis. He revisited the issue of whether the introduction of the European Economic and Monetary Union (EMU) and the Euro have had any impact on bank competition. Sun (2011) found that the level of bank competition converged across the Euro area in the wake of the EMU. Also, he discovered that the financial crisis of 2007-2008 led to a fall in competition in several countries, especially countries where large credit and housing booms had preceded the crisis. His study was conducted for the period 1995-2009. Leroy and Lucotte (2017), on their part, studied the relationship between competition and bank risk across a large sample of European banks from 2004-2013. Controlling for a variety of bank-specific and macroeconomic factors, they concluded that competition encourages bank risk-taking and also increases individual bank fragility. This is also due to the fact that banks are financial intermediaries whose liabilities are mainly short-term deposits and whose assets are usually short-and-long-term loans to businesses and consumers (Demirgüç-Kunt and Detragiache, 1998).

Based on the premise that financial integration in Europe should impact competition between markets (financial) and intermediaries to generate a convergence of both interest rates and margins among different countries, De Guevara, Maudos, and Pérez (2007) analysed both the evolution of the convergence in interest rates and the level of competition and its inequalities among the European banking system for the period 1993-2001. They found that specialization leads to different levels of competition. However, according to Liu, Molyneux, and Wilson (2013), national measures of competition may be inappropriate in cases where banks operate with a regional focus. In fact, the level of competition in the banking industry is likely to have far-reaching implications for economic growth, productivity, consumer welfare, and financial stability. By studying ten (10) European countries between the year 2000-2008, Liu, Molyneux, and Wilson (2013) found an inverted u-shaped relationship to exist between regional bank competition and stability.

Responses to the 2008 financial crisis have been to improve the prudential regulation via an increase of capital requirements as implemented by the Basel III agreements. As discussed earlier, in practice, regulation can directly weaken competition through restrictions on bank entries and also creating incentives to merge (Leroy and Lucotte, 2017). Capital requirements reduce risk in general, but for banks with market power, this effect significantly weakens.

Agoraki, Delis, and Pasiouras (2011) studied whether regulations have an independent effect on bank risk-taking or whether their effect is channelled through the market power possessed by banks. Using data from the Central and Eastern European banking sector over the period 1998-2005, they showed that banks with market power tend to take on lower credit risk and have a lower probability of default. Also Maudos and Vives (2019) examined the evolution of competition in the EU banking sector, focusing on its interaction with regulatory development and the parallel evolution of the application of competition policy in the sector. According to them, the crisis in 2008/2009 reversed some advances in competitive pressure that had occurred due to market integration and the introduction of the Euro. Maudos and Vives (2019) however suggested that there is enough room to improve both competition and stability in the banking sector by refining regulation. Menicucci and Paolucci (2016) on the other hand studied the relationship between 
bank-specific characteristics and profitability in the European banking sector to find the role of internal factors in achieving high profitability. Their studies sampled data of 35 top European banks over the period 2009-2013. They found that size and capital ratio are significant company-level determinants of bank profitability in Europe, while higher loan loss provisions result in lower profitability levels.

From the various literature reviewed, it is evident that most of the studies on competition in the banking or financial sector in the EU have studied competition prior to the financial crisis with little attention to the post-crisis period. Also based on the suggestion of Maudos and Vives (2019) discussed above, this paper will be exploring the question of whether competition has improved in the European banking sector since the financial crisis. Taking note of the fact that the degree of concentration is not necessarily related to the level of competition, this study will employ the use of both structural and non-structural measures of competition in the Consolidated European Banking sector.

Also, the efficiency of the banking system has direct implications for social welfare. The permanent changes in external and internal environment force commercial banks to continually change their strategy, vision, business and financial plans. The main reasons for exploring competitive conditions in the banking sector are also premised on the dominant role banks play in the provision of intermediation services and their capital formation processes in various economies (Palečková, 2018).

\section{Data and methodology}

Data for this study was sourced from the European Central Bank (ECB) database. The ECB is an official EU institution at the heart of the Euro-system as well as the single supervisory mechanism for banking supervision. The data represents annual consolidated banking data for domestic banking groups and stand-alone banks, foreign (EU and nonEU) controlled subsidiaries, and foreign (EU and non-EU) controlled branches for 26 countries from 2009 to 2017. The unit of measure is the Euro. Data unavailability proved to be a limiting criterion making it impossible to consider all 28 countries in the ECB database. In dealing with a few missing data issues, this study repeated the last available year's data for the year for which there was missing data.

Several studies have employed various methods in measuring competitive conditions in the banking sector. The most important methods used include the use of both structural and non-structural concentration measures. Structural measures involve concentration ratios such as the Herfindahl-Hirschman Index (HHI), Theil Index, Lerner Index, etc. For this measure, the higher the concentration ratio, the less competitive the sector may be, and vice versa. Non-structural measures mainly include the Panzar and Rosse (1987) Hstatistics and the Boone indicator. The Theil index is an inequality index that breaks down the inequalities into a country and a specialization effect (De Guevara, Maudos, and Pérez, 2007). The Lerner index measures competition by examining the difference between the output price and the marginal cost of production (scaled by the output price) at the firm level. It is more of a firm-level measure of competition and may vary over time (Assefa, Hermes, and Meesters, 2013). Like the other non-structural measures, the Boone-indicator is based on the relationship between performance, in terms of profits, and efficiency, measured as marginal costs. The assumption here is that in a competitive market, more efficient companies are likely to gain larger market shares than in a non-competitive 
market (Van Leuvensteijn, 2014). The choice of these indicators is still a subject of debate among scholars.

Sun (2011) used the H-statistic in his analysis of competition in the European banking sector. Leroy and Lucotte (2017) and Agoraki, Delis, and Pasiouras (2011) used the Lerner index in favour of the Panzar and Rosse (1987) H- statistics. Agoraki, Delis, and Pasiouras (2011) settled on the Lerner index because, according to them, other studies had suggested that the H-statistics does not map into a range of oligopoly solution concepts. Palečková (2018) used a combination of both concentration ratios and the HHI index - structural measures.

Casu and Girardone (2006), Baarsma and Vooren (2018), and Fungáčová, Shamshur, and Weill (2017) combined both structural and non-structural concentration measures to analyse the level of competition in the European banking sector.

\section{Table 1. Interpretation of the $\boldsymbol{H}$ - Statistic (Rosse - Panzar)}

\section{Equilibrium test}

$E=0 \quad$ Equilibrium

$E<0 \quad$ Disequilibrium

\section{Competitive Conditions}

$H \leq 0 \quad$ Monopoly or conjectural short-run oligopoly.

$H=1 \quad$ Perfect competition or natural monopoly in a perfectly contestable

market or sales maximising firm subject to break even constraint

$0<H<1 \quad$ Monopolistic competition

Source: Papapetrou, E., Lolos, S., Hondroyinnis, G., 1999.

In addition to the structural measures, this paper will also use the H-statistics, developed by Panzar and Rosse (1987), which has been widely used to measure competition in the banking sector due to its broad applicability and ease of estimation. The H-statistics investigates the relationship between bank costs and bank revenues. The $\mathrm{H}$-statistics will be estimated for Euro area countries over the period 2009-2017. The equations to be estimated are shown below.

$$
\begin{gathered}
\operatorname{InOPI}_{\text {it }}=\alpha_{0}+\alpha_{1} \operatorname{InPL}_{\mathrm{it}}+\alpha_{2} \operatorname{InPK}_{\mathrm{it}}+\alpha_{3} \operatorname{InPF}_{\mathrm{it}}+\beta_{1} \operatorname{InRAST}_{\mathrm{it}} \\
+\beta_{2} \operatorname{InAST}_{\mathrm{it}}+\beta_{3} \operatorname{InBR}_{\mathrm{it}}+\varepsilon_{\mathrm{it}} \\
\operatorname{InNII}_{\mathrm{it}}=\alpha_{0}+\alpha_{1} \operatorname{InPL}_{\mathrm{it}}+\alpha_{2} \operatorname{InPK}_{\mathrm{it}}+\alpha_{3} \operatorname{InPF}_{\mathrm{it}}+\beta_{1} \operatorname{InRAST}_{\mathrm{it}} \\
+\beta_{2} \operatorname{InAST}_{\mathrm{it}}+\beta_{3} \operatorname{InBR}_{\mathrm{it}}+\varepsilon_{\mathrm{it}} \\
\mathrm{ROA}_{\mathrm{it}}=\alpha_{0}^{\prime}+\alpha_{1}^{\prime} \operatorname{InPL}_{\mathrm{it}}+\alpha_{2}^{\prime} \operatorname{InPK}_{\mathrm{it}}+\alpha_{3}^{\prime} \operatorname{InPF}_{\mathrm{it}}+\beta_{1}^{\prime} \operatorname{InRAST}_{\mathrm{it}} \\
+\beta_{2}^{\prime} \operatorname{InAST}_{\mathrm{it}}+\beta_{3}^{\prime} \operatorname{InBR}_{\mathrm{it}}+\mu_{\mathrm{it}}
\end{gathered}
$$

Where OPI is the ratio of bank operating income to total assets, NII is the net interest income as a fraction of total assets, ROA is the return on assets expressed in percentages, $\mathrm{PL}$ is the ratio of staff expenses to the number of employees, PK is the ratio of capital expenses to fixed assets, PF is the ratio of interest expense to own funds, RAST is the ratio of provisions to total assets - a measure of the riskiness of overall bank portfolio, 
AST is the total assets - a proxy for size and BR is the ratio of the number of branches in a country to the total number of branches in the EU. The subscripts $i$ and $t$ denote the number of banks and time, respectively. $\varepsilon_{\text {it }}$ and $\mu_{\mathrm{it}}$ denote a one-way error component. According to Palečková (2018), the OPI, NII, and ROA are traditional measures of measuring bank profitability.

Equations (1) and (2) are models of competitive conditions in the Consolidated European banking sector. The $H-$ Statistics is given by $H=\alpha_{1}+\alpha_{2}+\alpha_{3}$. Equation (3) is a model of the equilibrium condition. The banking sector will be in equilibrium if $E=\alpha_{1}^{\prime}+\alpha_{2}^{\prime}+\alpha_{3}^{\prime}$ $=0$ (Matthews et al., 2007).

A panel Kao residual cointegration test conducted - with a no deterministic trend assumption - rejected the null hypothesis of no cointegration in the variables. The correlation matrix shows a significant relationship between the ratio of operating income to total assets and the other variables. The return on assets displayed the weakest correlation with most of the variables.

Table 2. Correlation Matrix for Variables

\begin{tabular}{|c|c|c|c|c|c|c|c|c|c|}
\hline & LnOPI & ROA & LnNII & LnPF & LnPK & $\overline{L n P L}$ & LnRAST & LnBR & LnAST \\
\hline LnOPI & 1 & & & & & & & & \\
\hline $\mathrm{ROA}$ & $0.17^{*}$ & 1 & & & & & & & \\
\hline LnNII & $0.83^{*}$ & 0.06 & 1 & & & & & & \\
\hline LnPF & $-0.15^{\star *}$ & $-0.33^{*}$ & -0.01 & 1 & & & & & \\
\hline LnPK & $0.30^{*}$ & -0.01 & $0.39^{*}$ & $-0.33^{*}$ & 1 & & & & \\
\hline LnPL & $-0.60^{*}$ & $-0.16^{*}$ & $-0.53^{*}$ & $0.32^{*}$ & $-0.60^{*}$ & 1 & & & \\
\hline LnRAST & $0.17^{\star}$ & $-0.12^{\star \star \star}$ & 0.10 & $0.23^{*}$ & $-0.34^{*}$ & $0.27^{*}$ & 1 & & \\
\hline LnBR & $-0.11^{* * *}$ & 0.01 & $-0.34^{*}$ & $0.12^{* *}$ & $-0.44^{*}$ & $0.16^{\star *}$ & $0.25^{*}$ & 1 & \\
\hline LnAST & $-0.50^{*}$ & -0.07 & $-0.61^{*}$ & $0.31^{*}$ & $-0.77^{*}$ & $0.74^{*}$ & $0.37^{*}$ & $0.55^{*}$ & 1 \\
\hline
\end{tabular}

Significance level: $* 1 \%$, **5\%, ***10\%

Since the null of no cointegration in the variables were rejected, a Fully Modified Ordinary Least Square (FMOLS) estimation method was used in this study. The method used in this study is a straight forward extension of the FMOLS model used by Phillips and Hansen (1990). The extension was motivated by the works of Phillips and Moon (1999), Pedroni (2001), and Kao and Chiang (2001). The FMOLS estimator is given by equation 4 below.

$$
\beta_{F P}=\left[\sum_{i=1}^{N} \sum_{t=1}^{T} X_{i t} X_{i t}^{\prime}\right]^{-1} \sum_{i=1}^{N} \sum_{t=1}^{T}\left(X_{i t} \hat{Y}_{i t}^{+}-\hat{\lambda}_{12}^{+}\right)
$$

Given estimates of the average long-run covariances, $\hat{\lambda}$ and $\widehat{\Omega}$, the modified dependent variable and serial correlation correction terms are defined in equations 5 and 6 below.

$$
\begin{aligned}
& \hat{Y}_{i t}^{+}=\hat{Y}_{i t}-\widehat{w}_{12} \Omega_{22}^{-1} \hat{\mu}_{2} \\
& \hat{\lambda}_{12}^{+}=\hat{\lambda}_{12}-\widehat{w}_{12} \Omega_{22}^{-1} \hat{\lambda}_{2}
\end{aligned}
$$


Where $Y_{i t}$ and $X_{i t}$ are the corresponding data purged of the individual deterministic trends and $\widehat{w}_{12}$ is the long-run average variance of $\mu_{1 i t}$ conditional on $\mu_{2 i t} . Y_{i t}$ and $X_{i t}$ are also the demeaned variables in the leading case of individual-specific intercepts. As a result of the use of FMOLS model, the sample was adjusted to 2010 to 2017. The Eviews software was used to estimate the results.

\section{Results and analysis}

Per the structural method used (concentration ratios), market concentration - calculated by the consolidated bank total assets - has increased in the EU. Maudos and Vives (2019) note Hungary, Czech Republic, Denmark, Finland, and Slovenia as exceptions. As shown in Table 3, the top five (5) countries - United Kingdom, France, Germany, Spain, and Italy - in terms of consolidated bank assets, control over 70 percent of the assets in subregion. The percentage increased from 72.4 per cent in 2009 to 73.5 per cent in 2017 . Within this, the top two country's control of assets in the EU has decreased over the same period. The HHI index computed for all countries over the same period will however suggest a moderate to a high concentration in Europe. This means that the consolidated banking sector in Europe is not competitive and is dominated by the banking sectors of the top 5 countries in terms of assets - an indication of an oligopolistic to monopolistic competition.

Table 3: Concentration ratios and HHI of the consolidated banking sector

\begin{tabular}{rccc}
\hline Year/Measure & CR2 & CR5 & HHI \\
\hline 2009 & 42.649 & 72.420 & 1330.112 \\
2014 & 38.954 & 73.439 & 1308.556 \\
2017 & 37.871 & 73.494 & 1295.314 \\
\hline
\end{tabular}

Source: European Central Bank (ECB) database (2017)

Table 4 shows the regression result for equations 1,2, and 3. The result shows that staff expenses to the number of employees and total assets were significant at explaining the operating income and the net interest income in the sub-region. Thus a unit increase in both the log of the operating income and the net-interest income leads to a 42.5 per cent and 59.7 per cent increase respectively in the ratio of staff expense to the number of employees. Interest expense to own funds was only significant in explaining net-interest income and the return on assets. The most important thing of note is the relative importance of the ratio of capital expense to fixed assets (PK) and assets (AST) in the Europe area. They were both negatively related to the operating income and the net interest income. They are indicating that the accumulation of assets - investing in stocks - eats into the incomes of banks in the sub-region, whereas bank exposures may also be affecting bank profits. It is thus not surprising that the ratio of capital expense to fixed assets is also negatively related to return on assets and very significant. The results also show that the relationship between the log of the ratio of provisions to total assets (RAST) - a measure of the riskiness of the overall bank portfolio - and the dependent variables was not significant. This confirms the findings of Menicucci and Paolucci (2016), who discovered a significant relationship between size and capital ratio and bank profitability in Europe. 
Table 4. Regression Output for Equations 1, 2 and 3

\begin{tabular}{lccc}
\hline \multirow{2}{*}{ Explanatory Variables } & \multicolumn{3}{c}{ Dependent Variable } \\
\cline { 2 - 4 } LnPL & LnOPI & LnNII & ROA \\
& 0.425 & 0.597 & 0.546 \\
LnPK & $(4.810)^{\star}$ & $(9.778)^{\star}$ & 1.138 \\
& -0.114 & -0.040 & -0.524 \\
LnPF & $(-3.306)^{*}$ & $(-1.685)^{\star * *}$ & $(-2.801)^{\star}$ \\
& 0.018 & 0.091 & -0.380 \\
LnRAST & $(0.937)$ & $(6.702)^{\star}$ & $(-3.580)^{\star}$ \\
& -0.005 & -0.014 & 0.093 \\
LnAST & $(-0.234)$ & $(-0.961)$ & $(0.839)$ \\
& -1.099 & -0.876 & -1.362 \\
LnBR & $(-11.261)^{\star}$ & $(-12.991)^{\star}$ & $(-2.570)^{\star *}$ \\
& -0.173 & 0.130 & -0.609 \\
R-squared & $(-1.813)^{* * *}$ & $(1.972)^{*}$ & $(-1.174)$ \\
Adjusted R-squared & 0.879 & 0.971 & 0.503 \\
\end{tabular}

$* 1 \%$, **5\%, ***10\%; t-statistics in parenthesis ()

To measure competition in the consolidated banking sector in the European Union we first test for equilibrium using equation (3). To do this, we sum the input prices to check if they are jointly equal to zero $(\mathrm{E}=0)$. The result shows that they are not equal to zero, pointing to a disequilibrium in the sector. A Wald test conducted to check the significance of this result showed it not to be significant. The test for competitive conditions in both equations 1 and 2 showed the presence of monopolistic competition in the consolidated banking sector in Europe. This is because the sum of the input prices - LnPL, LnPK, and LnPF - were greater than zero but less than one. The Wald test conducted showed this conclusion to be significant at a 1 per cent significance level. This conclusion is consistent with the study by Molyneux, Lloyd-Williams and Thornton (1994).

In Monopolistic competition, Panzar and Rosse (1987) assume that the firms are in longrun equilibrium and earn zero economic profit. Unlike a monopoly - a single firm operating in a sector, the demand curve facing a monopolistic competitive firm is dependent on the number of rivals, the prices and quantities of the substitute goods in the market. As noted earlier, a cointegration test conducted on all the variables rejects the null of no cointegration in the variables. A pointer to a long-run relationship between the variables. Contrary to the Panzar and Rosse (1987) assumption of long-run equilibrium under a monopolistic competitive sector, this study found a disequilibrium in the sector. This was, however, not significant. 
Table 5. H-Statistics Result

\begin{tabular}{|c|c|c|c|c|c|}
\hline \multicolumn{6}{|c|}{ Test of equilibrium dependent variable ROA } \\
\hline Period & LnPL & LnPK & LnPF & Sum $E$ & HO: Sum =0 \\
\hline $2010-2017$ & 0.546215 & -0.523653 & -0.380085 & -0.357523 & Prob-F $(1,176)=0.5114$ \\
\hline \multicolumn{6}{|c|}{$\mathrm{H}$-statistics dependent variable LnOPI } \\
\hline Period & LnPL & LnPK & LnPF & Sum $H$ & HO: Sum=1 \\
\hline $2010-2017$ & 0.425105 & -0.113726 & 0.018322 & 0.329701 & Prob- $F(1,176)=0.0000$ \\
\hline \multicolumn{6}{|c|}{$\overline{H \text {-statistics dependent variable LnNII }}$} \\
\hline Period & LnPL & LnPK & LnPF & Sum $H$ & H0: Sum $=1$ \\
\hline $2010-2017$ & 0.59728 & -0.040058 & 0.090535 & 0.647757 & Prob- $F(1,176)=0.0000$ \\
\hline
\end{tabular}

Source: Author's Construction

\section{Conclusion}

This study measured competitive conditions in the consolidated banking sector in 26 countries in Europe during periods after the 2009 Global financial crisis. The study showed that the literature is divided on the type of competitive conditions that exist in Europe's financial sector, with most of the studies focusing on periods before the 2009 financial crisis. The literature reviewed showed that early studies of competition in the financial sector argue that if the banking system were competitive (low concentration), the banking system would be more stable. Others found that more concentrated systems are much more protected against risk (Chanet al. 2008, cited by Çifter, 2015). Other studies have also shown that there is no significant correlation between bank competition and bank stability or performance.

To fully capture competitive conditions in the consolidated banking sector of Europe, this study used both structured (concentration ratios) and non-structured (Panzar and Rosse H-statistics) methods of measurement. The results of both measures showed that the sector exhibits signs of a monopolistic competitive sector. The most important thing of note is the relative importance of the ratio of capital expense to fixed assets and assets in the Europe area. They were both negatively related to the operating income, net interest income, and the return on assets. They are indicating that the accumulation of assets - investing in stocks - eats into the incomes of banks in the sub-region whereas bank exposures may be affecting bank profits. Over the study period, the United Kingdom, France, Germany, Spain, and Italy control 70 per cent of assets in the sector.

Based on these results, one can clearly say that competitive conditions have not improved after the 2009 financial crisis. This confirms the observations by Maudos and Vives (2019) that the financial crisis reversed some advances in competitive pressure that had occurred due to market integration and the introduction of the Euro. To effectively keep track of progress in the sector, the recent GCI (2018) $-9^{\text {th }}$ Pillar (financial system) - has now included non-technological indicators such as domestic credit to the private sector, financing of SMEs, venture capital availability, market capitalization, soundness of banks, bank regulatory capital, credit gap and etc. to its list of indicators. 
It is going to take time for competitive conditions to improve in the European Consolidated Banking Sector. This has been compounded by the Coronavirus pandemic, which has the tendency to push banks to limit their risk assessment levels. This could lead to a similar crisis as witnessed during the 2008/09 financial crisis if bank supervision and remedial measures are not stepped up - even though the risk assessment variable was not significant in this study. There is the need to proceed with care, and past lessons must guide reforms going forward to ensure that the conditions that led to the financial crisis do not re-exert itself. Primacy must also be given to less developed banks in the sector to ensure financial inclusion. An avenue for further studies will be to extend the study period to 2018, which can then be compared to the GCI 2018, and also apply the Boone-indicator to see if the conclusions will still hold.

Disclosure statement: No potential conflict of interest was reported by the author.

\section{References}

ABIDIN, I.S.Z., BAKAR, N.A.A. AND HASEEB, M., (2014). An empirical analysis of exports between Malaysia and TPP member countries: Evidence from a panel cointegration (FMOLS) model. Modern Applied Science, 8(6), p.238.

AGORAKI, M.E.K., DELIS, M.D. AND PASIOURAS, F., (2011). Regulations, competition and bank risk-taking in transition countries. Journal of Financial Stability, 7(1), pp.38-48. DOI: $10.1016 /$ j.jfs.2009.08.002

ASSEFA, E., HERMES, N. AND MEESTERS, A., (2013). Competition and the performance of microfinance institutions. Applied Financial Economics, 23(9), pp.767-782. DOI: $10.1080 / 09603107.2012 .754541$

BAARSMA, B. AND VOOREN, M., (2018). Bank competition and the transmission of unconventional monetary policy in the euro area. European Competition Journal, 14(1), pp.174-193. DOI: $\underline{10.1080 / 17441056.2018 .1463688}$

CASU, B. AND GIRARDONE, C., (2006). Bank competition, concentration and efficiency in the single European market. The Manchester School, 74(4), pp.441-468. DOI: 10.1111/j.1467-9957.2006.00503.x

ÇIFTER, A., (2015). Bank concentration and non-performing loans in Central and Eastern European countries. Journal of Business Economics and Management, 16(1), pp.117137. DOI: $10.3846 / 16111699.2012 .720590$

DE GUEVARA, J.F., MAUDOS, J. AND PÉREZ, F., (2007). Integration and competition in the European financial markets. Journal of International Money and $\mathrm{Fi}$ nance, 26(1), pp.26-45. DOI: 10.1016/j.jimonfin.2006.10.008

DEMIRGÜÇ-KUNT, A. AND DETRAGIACHE, E., (1998). The determinants of banking crises in developing and developed countries. Staff Papers, 45(1), pp.81-109. DOI: $\underline{10.2307 / 3867330}$

DELIS, M.D., (2010). Competitive conditions in the Central and Eastern European banking systems. Omega, 38(5), pp.268-274. DOI: 10.1016/j.omega.2008.09.002 
FUNGÁČOVÁ, Z., SHAMSHUR, A. AND WEILL, L., (2017). Does bank competition reduce cost of credit? Cross-country evidence from Europe. Journal of Banking \& Finance, 83,pp.104-120. DOI: 10.1016/j.jbankfin.2017.06.014

KAO, C. AND CHIANG, M.H., (2001). On the estimation and inference of a cointegrated regression in panel data. In Nonstationary panels, panel cointegration, and dynamic panels (pp. 179-222). Emerald Group Publishing Limited.

LEROY, A. AND LUCOTTE, Y., (2017). Is there a competition-stability trade-off in European banking?. Journal of International Financial Markets, Institutions and Money, 46, pp.199-215. DOI: 10.1016/j.intfin.2016.08.009

LIU, H., MOLYNEUX, P. AND WILSON, J.O., (2013). Competition and stability in European banking: a regional analysis. The Manchester School, 81(2), pp.176-201. DOI: 10.1111/j.1467-9957.2011.02285.x

MAUDOS, J. AND VIVES, X., (2019). Competition Policy in Banking in the European Union. Review of Industrial Organization, pp.1-20.

MOLYNEUX, P., LLOYD-WILLIAMS, D.M. AND THORNTON, J., (1994). Competitive conditions in European banking. Journal of banking \& finance, 18(3), pp.445-459. DOI: $\underline{\text { 10.1016/0378-4266(94)90003-5 }}$

PALEČKOVÁ, I., (2018). Performance Measurement in Banking: Empirical Application to Central and Eastern Europe. Professional Publishing.

PANZAR, J.C. AND ROSSE, J.N., (1987). Testing for" monopoly" equilibrium. The journal of industrial economics, pp.443-456.

PEDRONI, P., (2001). Fully modified OLS for heterogeneous cointegrated panels. In Nonstationary panels, panel cointegration, and dynamic panels (pp. 93-130). Emerald Group Publishing Limited.

PHILLIPS, P.C. AND HANSEN, B.E., (1990). Statistical inference in instrumental variables regression with I (1) processes. The Review of Economic Studies, 57(1), pp.99-125. DOI: $\underline{10.2307 / 2297545}$

PHILLIPS, P.C. AND MOON, H.R., (1999). Linear regression limit theory for nonstationary panel data. Econometrica, 67(5), pp.1057-1111. DOI: $\underline{10.1111 / 1468-0262.00070}$

PRADHAN, K.C., (2016). Does remittance drive economic growth in emerging economies: Evidence from FMOLS and Panel VECM. Theoretical \& Applied Economics, 23(4).

SUN, M.Y., (2011). Recent developments in European bank competition (No. 11-146). International Monetary Fund.

VAN LEUVENSTEIJN, M., (2014). The Boone-indicator: Identifying different regimes of competition for the American Sugar Refining Company 1890-1914. Tjalling C. Koopmans Institute, 8(37). 


\section{Appendix}

Figure 1: GCI (8 ${ }^{\text {th }}$ Pillar) and GDP per Capita (PPP)

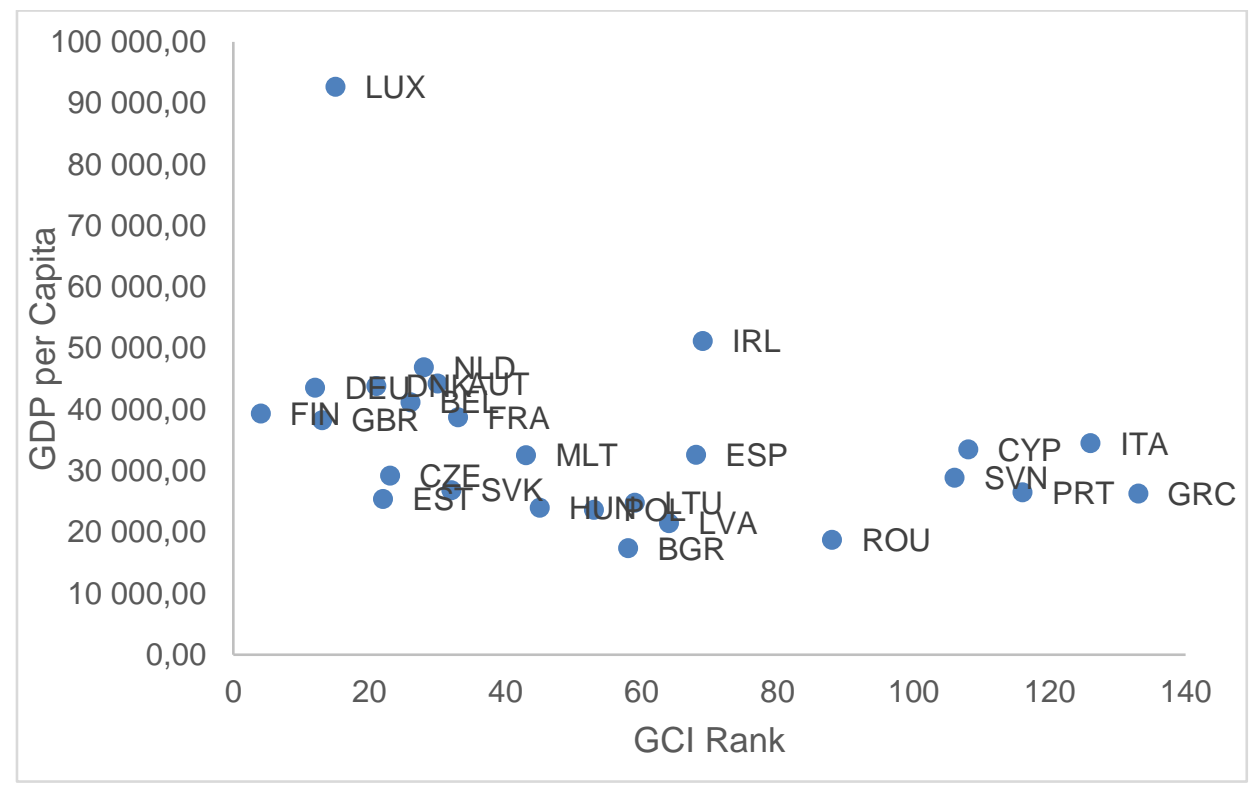

Source: GCI and IMF 
Review of Economic Perspectives

Table 1: Descriptive Statistics

\begin{tabular}{lccccccccc}
\hline & LnOPI & ROA & LnNII & LnPF & LnPK & LnPL & LnRAST & LnBR & LnAST \\
\hline Mean & -3.66 & 0.23 & -4.17 & -1.70 & -1.01 & 4.00 & -5.86 & -4.26 & 19.72 \\
Median & -3.60 & 0.41 & -4.16 & -1.64 & -0.95 & 4.15 & -5.67 & -4.72 & 19.84 \\
Maximum & -2.78 & 3.14 & -3.16 & 2.90 & 0.72 & 5.28 & -3.91 & -0.96 & 23.22 \\
Minimum & -6.63 & -7.99 & -5.41 & -3.94 & -3.02 & 2.35 & -9.95 & -5.79 & 16.80 \\
Std. Dev. & 0.45 & 1.15 & 0.53 & 0.81 & 0.76 & 0.75 & 1.14 & 1.23 & 1.87 \\
Skewness & -1.32 & -2.97 & -0.34 & 0.32 & -0.09 & -0.30 & -0.89 & 0.99 & 0.15 \\
Kurtosis & 9.96 & 17.35 & 2.61 & 7.05 & 2.48 & 1.89 & 3.46 & 3.25 & 1.85 \\
Jarque-Bera & 539.952353 .01 & 6.09 & 164.20 & 2.92 & 15.50 & 33.04 & 38.80 & 13.83 \\
Probability & 0.00 & 0.00 & 0.05 & 0.00 & 0.23 & 0.00 & 0.00 & 0.00 & 0.00 \\
Sum & -856.09 & 54.74 & -975.02 & -396.75 & -237.16 & 936.41 & -1371.50 & -996.24 & 4613.57 \\
Sum Sq. & 46.89 & 309.69 & 65.16 & 154.59 & 135.44 & 132.05 & 302.64 & 354.54 & 810.03 \\
Dev. & & & & & & & & \\
Observa- & 234 & 234 & 234 & 234 & 234 & 234 & 234 & 234 & 234 \\
tions & & & & & & & & & \\
\hline
\end{tabular}

